\title{
Invited review: Palmitic and stearic acid metabolism in lactating dairy cows
}

\author{
J. R. Loften, ${ }^{*}$ J. G. Linn, ${ }^{\star 1}$ J. K. Drackley,† T. C. Jenkins, † C. G. Soderholm, ${ }^{*}$ and A. F. Kertz§ \\ *Milk Specialties Global, Eden Prairie, MN 55344 \\ †Department of Animal Sciences, University of Illinois, Urbana 61801 \\ ‡Department of Animal and Veterinary Sciences, Clemson University, Clemson, SC 29634 \\ $\S$ Andhil LLC, St. Louis, MO 63122
}

\section{ABSTRACT}

Energy is the most limiting nutritional component in diets for high-producing dairy cows. Palmitic (C16:0) and stearic (C18:0) acids have unique and specific functions in lactating dairy cows beyond a ubiquitous energy source. This review delineates their metabolism and usage in lactating dairy cows from diet to milk production. Palmitic acid is the fatty acid (FA) found in the greatest quantity in milk fat. Dietary sources of C16:0 generally increase milk fat yield and are used as an energy source for milk production and replenishing body weight loss during periods of negative energy balance. Stearic acid is the most abundant FA available to the dairy cow and is used to a greater extent for milk production and energy balance than C16:0. However, C18:0 is also intimately involved in milk fat production. Quantifying the transfer of each FA from diet into milk fat is complicated by de novo synthesis of $\mathrm{C} 16: 0$ and desaturation of $\mathrm{C} 18: 0$ to oleic acid in the mammary gland. In addition, incorporation of both FA into milk fat appears to be limited by the cow's requirement to maintain fluidity of milk, which requires a balance between saturated and unsaturated FA. Oleic acid is the second most abundant FA in milk fat and likely the main unsaturated FA involved in regulating fluidity of milk. Because the mammary gland can desaturate C18:0 to oleic acid, C18:0 appears to have a more prominent role in milk production than C16:0. To understand metabolism and utilization of these FA in lactating dairy cows, we reviewed production and milk fat synthesis studies. Additional and longer lactation studies on feeding both FA to lactating dairy cows are required to better delineate their roles in optimizing milk production and milk FA composition and yield.

Key words: stearic acid, palmitic acid, milk fat, milk production, body condition

Received January 8, 2014

Accepted April 27, 2014.

${ }^{1}$ Corresponding author: jlinn@milkspecialties.com

\section{INTRODUCTION}

Energy is and will continue to be the major nutritional challenge to the ever-increasing lactation productivity of dairy cows. Because of this, dairy producers and nutritionists have increased the use of high-energy feed ingredients, such as fat, in lactating dairy cow diets. Dry, ruminally inert fat supplements have become common feed ingredients in diets because of their energy content and versatility on farms, where they can be added to grain mixes, mineral mixes, TMR, or top dressed. Dry, rumen-inert fats usually contain high concentrations of long-chain FA (LCFA), with the most common being palmitic (C16:0), stearic (C18:0), oleic (C18:1), and linoleic (C18:2). Research over the last several years has shown FA are not just a ubiquitous source of energy, but have metabolically different functions in the cow and contribute to the productive function of cows in different ways. This paper discusses the roles of C16:0 and C18:0, the 2 most common SFA found in rumeninert fats, in the metabolism and productivity of lactating dairy cows.

\section{CHEMICAL PROPERTIES OF PALMITIC AND STEARIC ACIDS}

Palmitic acid is a 16-carbon SFA denoted as $n$-hexadecanoic acid with a chemical formula of $\mathrm{CH}_{3}\left(\mathrm{CH}_{2}\right)_{14} \mathrm{CO}_{2} \mathrm{H}$. It has a melting point of $62.8^{\circ} \mathrm{C}$ and a $\mathrm{p} K_{\mathrm{a}}$ (acid dissociation constant) of 4.78 (Budavari, 1989). French scientist Michel Eugene Chevreul discovered palmitic acid in the early 1800s (Lemay and Oesper, 1948) and it was first used by the French chemist Edmond Frémy in the middle 1800s for the making of candles. Palmitic acid is the most common SFA found in plants, animals, and many microorganisms. Major sources of C16:0 are palm oil, palm kernel oil, coconut oil, and milk fat.

Stearic acid is an 18-carbon SFA denoted as $n$-octadecanoic acid with a chemical formula of $\mathrm{CH}_{3}\left(\mathrm{CH}_{2}\right)_{16} \mathrm{CO}_{2} \mathrm{H}$. Michel Eugene Chevreul first described C18:0 in the early 1800s (Lemay and Oesper, 1948). Stearic acid is a prevalent FA in nature, found in many animal and 
vegetable fats, but is usually higher in animal fat than vegetable fat. It has a melting point of $69.4^{\circ} \mathrm{C}$ and a $\mathrm{p} K_{\mathrm{a}}$ of 4.50 (Sukhija and Palmquist, 1990).

\section{DIGESTION AND ABSORPTION}

Most naturally occurring fats consumed by the dairy cow are in the form of triacylglycerols (TAG), phospholipids, and glycolipids. Bacteria and protozoa in the rumen hydrolyze these complex lipids into LCFA, glycerol, sugars, choline, serine, phosphates, and other organic compounds (Buccioni et al., 2012). The number of rumen microorganisms capable of hydrolyzing esterified lipids is low, but their activity is highly specific and efficient, as 85 to $95 \%$ of the dietary lipids reaching the duodenum are FFA (Doreau and Ferlay, 1994; Buccioni et al., 2012). Only unsaturated FFA released during hydrolysis can be biohydrogenated to saturated FFA, primarily $\mathrm{C} 18: 0$ and secondarily $\mathrm{C} 16: 0$. However, the biohydrogenation process is not entirely complete and some intermediate unsaturated FA exit the rumen, including isomers that may cause milk fat depression (Jenkins et al., 2008; Bauman et al., 2011; Buccioni et al., 2012).

\section{FA Flow into the Duodenum}

The flow of C18:0 from the rumen is several times greater than the amount consumed because of biohydrogenation of PUFA in the forages and grains fed to dairy cows. Wu et al. (1991) was one of the first studies to show that C18:0 was the only FA to increase in amount flowing from the rumen above the amount fed with or without fat supplemented in the diet. Outflow of C18:0 from the rumen was 46, 24, and $44 \%$ of the total FA intake (Table 1) when no supplemental fat, rumen-inert fat, or animal-vegetable $(\mathbf{A V})$ blend fat was fed in a diet of $40 \%$ concentrate and $60 \%$ forage (alfalfa hay, haylage, and corn silage). Intake and rumen outflow of C16:0 remained similar, at 71 and 83 $\mathrm{g}$, respectively, when no fat was supplemented in the diet, but with rumen-inert or AV supplementation, outflow of C16:0 was less than intake. Wu et al. (1991) also fed a rumen-inert fat high in C16:0 and cis-18:1 that changed amount and profile of FA intake and flow from the rumen; but, as a result of biohydrogenation, 6 times more C18:0 was flowing into the duodenum than the amount fed. Stearic acid was the only FA where the amount flowing from the rumen was greater than amount fed (Table 1).

Loor et al. (2004) also showed C18:0 was only 2.1 to $2.4 \%$ of the total FA fed in a high- $(65 \%)$ or lowconcentrate $(35 \%)$ diet, but the amount flowing into the duodenum was 25 times higher than the amount fed and accounted for 46 to $39 \%$ of the total FA flow leaving the rumen in the low- and high-concentrate diets, respectively. Supplementing $3.0 \%$ linseed oil in these diets increased $\mathrm{C} 18: 0$ to about $3.3 \%$ of the total FA fed and changed the $\mathrm{C} 18: 0$ in the FA flowing into the duodenum to 54 and $30 \%$ for low- and high-concentrate diets, respectively. In all diets, the amount of C18:0 flowing into the duodenum was higher than for any other FA. Changes in C16:0 from intake to duodenal flow were much less than for C18:0 with C16:0 intakes between 10 to $21 \%$ of the total FA fed and 10 to $17 \%$ of the total duodenal FA flow (Loor et al., 2004).

The effects of feeding multiple ingredients and supplemental fats on microbial metabolism of FA in the rumen and FA flow into the duodenum are reported in the meta-analysis of Glasser et al. (2008b) on digestion of FA in ruminants. Stearic acid was the predominant FA flowing from the rumen, at $69.5 \%$ of the total FA flow into the duodenum when fish meal was not included in the diet; but including fish meal decreased C18:0 to $34 \%$ and increased trans-C18:1 to $45 \%$ of the FA flow to the duodenum. Amounts of C18:0 flowing from the rumen in general were 3 times greater than flow of C16:0.

On exiting the rumen, most FA are present as salts of sodium, potassium, or calcium combined in an insoluble particulate phase of feed particles and microbial cells. These salts are dissociated and protonated to a great extent in the abomasum due to low $\mathrm{pH}$, and thus enter the duodenum mostly as nonionized FFA. If these FFA are not absorbed, they may reform as salts as $\mathrm{pH}$

Table 1. Fatty acid intake and rumen outflow in cows fed a $40 \%$ concentrate diet without fat (control) or with rumen-inert fat or animal-vegetable blend $(\mathrm{AV})^{1}$

\begin{tabular}{lccc}
\hline & \multicolumn{3}{c}{ Fat supplementation } \\
\cline { 2 - 4 } $\mathrm{FA}^{2}{ }^{2} \mathrm{~g} / \mathrm{d}$ & Control & Rumen-inert $^{3}$ & $\mathrm{AV}$ blend $^{4}$ \\
\hline C16:0 & 71 & 400 & 165 \\
Intake & 83 & 313 & 152 \\
Outflow & & & \\
C18:0 & 12 & 39 & 104 \\
$\quad$ Intake & 186 & 254 & 410 \\
Outflow & & & \\
C18:1, total & 79 & 308 & 297 \\
Intake & 60 & 158 & 126 \\
Outflow & & & \\
Total FA & & & \\
Intake & 431 & 1,052 & 934 \\
Outflow & 402 & 837 & 810 \\
\hline
\end{tabular}

${ }^{1}$ Adapted from Wu et al. (1991).

${ }^{2}$ Rumen-inert and AV blend intake and outflow values are means of feeding supplements at 3 and $6 \%$ of the diet DM.

${ }^{3}$ The FA composition of the rumen inert fat was $50.8 \%$ C16:0, $4.2 \%$ C18:0, and $35.5 \%$ cis $\mathrm{C} 18: 1$.

${ }^{4}$ The FA composition of the AV blend was $17.0 \%$ C16:0, 17.2\% C18:0, and $34.5 \%$ cis $\mathrm{C} 18: 1$. 
increases during passage through the small intestine. In the duodenum, pancreatic secretions and bile dissociate FFA adsorbed on feed particles to enable micelle formation. Both bile and pancreatic secretions are required for this process; bile supplies bile salts and lecithin, and pancreatic juice provides phospholipase enzymes to convert lecithin to lysolecithin and bicarbonate to raise the $\mathrm{pH}$ for enzymatic activity (Freeman, 1969; Drackley, 2000). Freeman (1969) found that lysolecithin had a greater effect on solubility of C18:0 in micelles than any other natural or artificial amphiphiles tested. This is significant considering that C18:0 is the FA of the largest quantity flowing into the duodenum of ruminants and requiring the capability to desorb FFA from feed particles and bacteria to form micelles. Once micelles form, they facilitate transfer of FFA and other nonpolar lipids across the unstirred water layer of intestinal epithelial cells. Fatty acids and lysolecithin are likely absorbed from the jejunum, whereas bile salts are highly reabsorbed from the ileum and recirculated to bile for subsequent micelle formation (Doreau and Ferlay, 1994). Re-esterification of FA occurs in epithelial cells of the small intestine and the newly formed TAG and phospholipids are incorporated into chylomicrons and very low-density lipoproteins, which are transported mainly by the lymph to reach peripheral circulation (Freeman, 1969).

\section{FA Digestibility}

Early FA digestibility studies based values on whole tract disappearance of lipids that did not take into account disappearance of FA from the rumen, synthesis of FA by rumen microorganisms, or biohydrogenation of PUFA occurring in the rumen. From a meta-analysis of digestion and flows of FA in ruminants, Schmidely et al. (2008) estimated that 6 to $16 \%$ of total FA intake disappeared between the mouth and duodenum when FA intakes ranged from 50 to $120 \mathrm{~g} / \mathrm{kg}$ of diet DM. Most of this disappearance is thought to be medium-chain FA through either absorption from the rumen or metabolism (oxidation) in the rumen wall. It is theoretically possible LCFA could be absorbed from the rumen but unlikely, as most of the LCFA exit from the rumen with feed particles. In the same meta-analysis, Schmidely et al. (2008) estimated that $10.8 \pm 3.0 \mathrm{~g}$ of FA $/ \mathrm{kg}$ of DM intake flowing into the duodenum was of microbial origin, and two-thirds of the microbial FA was from the synthesis of C16:0 and C18:0. Other studies (Doreau and Ferlay, 1994; Sauvant and Bas, 2001) have made similar but slightly lower estimations of microbial FA synthesis, at 9.69 and $8.43 \mathrm{~g} / \mathrm{kg}$ of DMI.

Several studies have described and quantified biohydrogenation of PUFA in the rumen (Jenkins et al., 2008;
Bauman et al., 2011; Buccioni et al., 2012) and their ultimate conversion to C18:0 with complete biohydrogenation. As shown previously, the amount of C18:0 exiting the rumen greatly exceeds the amount fed because of biohydrogenation; as a result, individual digestibility of C18:1, C18:2, and linoleic acid (C18:3) will be overestimated and C18:0 digestibility underestimated when only amounts fed and excreted are considered. In an early review on FA digestibility from 15 experiments and 64 diets, Doreau and Ferlay (1994) concluded that mean digestibilities of $\mathrm{C} 16: 0$ and $\mathrm{C} 18: 0$ were 77.1 and $76.3 \%$, respectively. A subsequent and comprehensive summary by Lock et al. (2006) of 20 dairy cow digestion studies measuring digestibility between the duodenum and ileum or duodenum to feces, found similar digestibility values for C16:0 and C18:0 (Table 2). In a meta-analysis on FA digestion and flows in ruminants, Glasser et al. (2008a) calculated digestibility values for C16:0 and C18:0 similar to those of Doreau and Ferlay (1994) and Lock et al. (2006). All 3 summaries and the study by Doreau and Chilliard (1997) indicate that numerical differences in digestibility between C16:0 and C18:0 and those of other LCFA largely reflect individual experiment differences (Table 2). Demeyer and Doreau (1999) concluded similarly that differences in digestibility among individual FA contribute very little to variation in digestibility of dietary fats. It appears that the majority of this variation reflects differences among individual experiments, and relates to differences in diets and specific feed components. Schmidely et al. (2008) found that intestinal digestibility of FA tended to increase with increasing chain length, but digestibilities of total $\mathrm{C} 16$ and total $\mathrm{C} 18$ were similar, at 74.6 and $73.4 \%$, respectively. Using total C16 and C18 for digestibility eliminates biases from biohydrogenation in the rumen. They also found that absorption of C12 to C16 FA was linear with respect to flow into the duodenum. In a separate analysis of the same data set, Glasser et al. (2008b) found absorption of C18:0 was a quadratic function of its duodenal flow with decreasing apparent absorption at duodenal flows greater than 50 $\mathrm{g} / \mathrm{kg}$ of DM intake. The intestinal model proposed for C18:0 absorption was

$$
\begin{aligned}
18: 0_{\text {absorbed }} & (\mathrm{g} / \mathrm{kg} \text { of } \mathrm{DMI})=0.84 \times 18: 0_{\text {duodenum }} \\
& -0.0044 \times 18: 0^{2}{ }_{\text {duodenum. }} .
\end{aligned}
$$

The reason for diminishing absorption of C18:0 at high FA flows to the duodenum reported by Glasser et al. (2008b) is unknown, but likely is linked to lysolecithin availability and micelle formation (Freeman, 1969; Doreau, 1992), saturation of intestinal absorption sites for C18:0 (Kucuk et al., 2004), and adaptive 
Table 2. Digestibility of FA between the duodenum and ileum or feces

\begin{tabular}{lccc}
\hline FA, \% & $\begin{array}{c}\text { Lock et al. } \\
(2006)\end{array}$ & $\begin{array}{c}\text { Glasser et al. } \\
(2008 b)\end{array}$ & $\begin{array}{c}\text { Doreau and } \\
\text { Chilliard } \\
(1997)\end{array}$ \\
\hline Palmitic (C16:0) & 75 & & 79 \\
Stearic (C18:0) & 72 & 74 & 77 \\
Oleic (C18:1) & 80 & 79 & 85 \\
Linoleic (C18:2) & 78 & 72 & 83 \\
Linolenic (C18:3) & 77 & 70 & 76 \\
Total & 74 & & \\
\hline
\end{tabular}

mechanisms by the cow for maintaining a relatively consistent profile of FA in tissues and milk fat. Glasser et al. (2007, 2008a) reported yield of C4 to C16 milk FA decreases linearly as duodenal flow of C18:0 and other C18 FA increased. This supports adaptive changes in digestion and absorption of C18:0 and other long-chain SFA. Even if the percentage absorption of C18:0 is slightly decreased at high flows into the duodenum, it likely has limited significance because more C18:0 is present in the small intestine than any other FA and, therefore, the quantity absorbed relative to other FA is always much greater.

\section{INTERMEDIARY METABOLISM OF PALMITIC AND STEARIC ACIDS}

Whereas C16:0 and C18:0 are chemically similarboth are saturated and only differ by 2 carbon unitstheir metabolism in tissues of dairy cows is quite different. Douglas et al. (2007) found concentrations of C16:0, C18:0, and C18:1 differed among blood and body tissues and changed with progression of the lactation (Table 3). Weight percentages of C16:0, C18:0, and $\mathrm{C} 18: 1$ in plasma were similar during the dry period, but C16:0 and C18:1 increased following parturition and during negative energy balance, whereas C18:0 decreased (Table 3). In adipose tissue, C18:1 was about twice the concentration (g/100 g of FA) of C16:0, and C16:0 was about 3 times the concentration of C18:0. The high concentration of C18:1 in adipose tissue arises from activity of delta-9 desaturase, encoded by the stearoyl CoA desaturase gene, which converts C18:0 to C18:1 in adipose cells (Smith et al., 2006). Age, diet (forage-to-grain ratio), and FA composition of supplemented fat have been shown to affect desaturation of C18:0 to C18:1 in beef cattle; however, cis 9-C18:1 remains the predominant FA in ruminant adipose tissue (Smith et al., 2006; Choi et al. 2013) even though cis 9-C18:1 flow from the rumen into the duodenum is significantly less than C18:0. Activity of delta-9 desaturase is likely an adaptive mechanism in ruminants that allows for utilization of the predominant SFA absorbed from the intestine.

Prior to and shortly after parturition, plasma NEFA concentrations lead to increased hepatic uptake of FA, their subsequent esterification, and accumulation of TAG in the liver (Grummer, 1993). Drackley (1999) stated the liver is prone to increased NEFA esterification around calving. Contreras and Sordillo (2011) suggested that excessive accumulation of lipid components in hepatocytes and other cells could cause physical damage, including compression and reduction in size and number of organelles in transition cows. This could lead to apoptosis or induced cell death. The hepatic metabolism of NEFA is primarily controlled by the supply of NEFA to the liver and the uptake of NEFA by mitochondria is regulated by the activity of carnitine palmitoyltransferase. Liver TAG contents of C16:0, C18:0, and cis C18:1 (Table 3) were similar in the dry period; but, following parturition, C16:0 and cis C18:1 increased compared with $45 \mathrm{~d}$ prepartum whereas

Table 3. Fatty acid composition of tissues in pre- and postpartum dairy cows ${ }^{1}$

\begin{tabular}{|c|c|c|c|c|}
\hline \multirow{2}{*}{$\begin{array}{l}\text { Tissue, } \\
\mathrm{g} / 100 \mathrm{~g} \text { of } \mathrm{FA}\end{array}$} & \multicolumn{4}{|c|}{ Day relative to parturition } \\
\hline & -45 & 1 & 21 & 65 \\
\hline \multicolumn{5}{|l|}{ Adipose } \\
\hline C16:0 & 27.0 & 27.5 & & \\
\hline C18:0 & 10.7 & 10.8 & & \\
\hline C18:1 cis-9 & 49.4 & 48.1 & & \\
\hline \multicolumn{5}{|c|}{ Liver triacylglycerols } \\
\hline C16:0 & 26.8 & $42.3^{\mathrm{a}}$ & $39.0^{\mathrm{a}}$ & $26.0^{\mathrm{h}}$ \\
\hline C18:0 & 25.5 & $10.6^{\mathrm{b}}$ & $12.2^{\mathrm{b}}$ & $24.7^{\circ}$ \\
\hline C18:1 cis-9 & 23.9 & $26.6^{\mathrm{a}}$ & $26.6^{\mathrm{a}}$ & $17.2^{\mathrm{h}}$ \\
\hline \multicolumn{5}{|l|}{ Plasma } \\
\hline C16:0 & 16.7 & $18.2^{\mathrm{a}}$ & $14.5^{\mathrm{b}}$ & $12.2^{c}$ \\
\hline C18:0 & 16.5 & $15.6^{\mathrm{a}}$ & $13.9^{\mathrm{b}}$ & $13.7^{\mathrm{l}}$ \\
\hline C18:1 cis-9 & 18.0 & $19.6^{\mathrm{a}}$ & $20.1^{\mathrm{a}}$ & $14.5^{\mathrm{h}}$ \\
\hline
\end{tabular}


C18:0 decreased (Douglas et al., 2007). Rukkwamsuk et al. (2000) investigated the composition of FA in the adipose tissue, serum, and liver of prepartum cows restricted in energy intake or fed excess energy during the dry period. They found that concentrations of C16:0, C18:1, and C18:2 increased significantly in liver during the first week postpartum of cows fed for high-energy intake. Liver C16:0 concentrations decreased in wk 3 postpartum for energy-restricted cows, but liver C16:0 concentrations remained significantly higher in cows fed the high-energy diet prepartum. Litherland et al. (2011) found feeding of moderately excessive-energy diets ( $150 \%$ of requirement) early in the dry period affected palmitate metabolism in the liver at parturition. Cows fed the moderate-energy diet early in the dry period had a decreased capacity for palmitate oxidation in the liver at parturition favoring deposition of C16:0 in TAG.

In contrast, C18:0 concentrations in liver are relatively unaffected by energy balance during the dry period (Rukkwamsuk et al., 2000). Mashek and Grummer (2003a) observed no net uptake of C18:0 in the caprine liver when $0.3 \mathrm{~m} M$ concentrations of $\mathrm{C} 16: 0$ and C18:0 were perfused into the caudate lobe. However, C16:0 uptake was significantly increased compared with C18:0. Mashek and Grummer (2003b) observed a 2-fold increase in $\mathrm{C} 16: 0$ metabolism when $\mathrm{C} 18: 0$ was added to bovine cell hepatic cultures compared with C16:0 alone. This may aid in the removal of excess C16:0 in hepatocytes. Sato and Inoue (2006) observed similar increases of C16:0 in liver, subcutaneous adipose, and perirenal adipose tissues of cows with fatty liver, with C18:0 decreasing in liver and adipose tissue following parturition. These data indicate that C18:0 does not accumulate in tissues of cows in negative energy balance and cows metabolize C18:0 for energy (e.g., $\beta$ oxidation) in the liver and muscle or secrete large proportions of C18:0 through milk as both $\mathrm{C} 18: 0$ and C18:1.

Fatty acids can affect their own metabolism as well as the metabolism of other energy-yielding compounds by affecting gene transcription (Nakamura et al., 2014). Recent studies have suggested that $\mathrm{C} 16: 0$ and $\mathrm{C} 18: 0$ may be more important regulators of metabolism and gene transcription in ruminants than unsaturated FA, which is very different from nonruminant models (Bionaz et al., 2012). This may be an adaptive mechanism for ruminants to regulate metabolism in response to changes in availability of the more prevalent SFA. Availabilities of C16:0 and C18:0 may also signal changes in glucose metabolism (Bionaz et al., 2013). White et al. (2011) suggested that the circulating FA that are characteristically increased in transition cows may contribute to increased expression of pyruvate carboxylase mRNA to stimulate gluconeogenesis and maintain oxaloacetate for the tricarboxylic acid cycle. Stearic acid was shown to regulate pyruvate carboxylase promoters (P1, P2, and P3) in different tissues, with C18:0 suppressing promoter P1 and enhancing promoter P3 activity simultaneously. The ability of C16:0 to affect pyruvate carboxylase promoter activity was not tested. These data suggest that C18:0 contributes to the partitioning of energy during periods of upregulated gluconeogenesis, increased hepatic FA supply, or both. Based on knowledge gained from more widely studied species (Nakamura et al., 2014), it seems likely that C16:0 and C18:0 have widespread effects, and perhaps differential effects, on transcription of other metabolically important genes in dairy cows.

Furthermore, although outside of the scope of this review, polymorphisms in genes encoding important regulatory enzymes of lipid metabolism might respond differently to C16:0 and C18:0 availability. To our knowledge, such potential differences have not yet been investigated, but the number of genetic polymorphisms known to affect FA metabolism in cattle is increasing rapidly. For example, in dairy cows, polymorphisms of diacylglycerol acyltransferase 1 (DGAT1) have been associated with a higher content of C16:0 and lower contents of C14:0, unsaturated C18, and CLA (Schennink et al., 2007). The gene DGAT1 encodes the DGAT1 microsomal enzyme, which catalyzes the last step in TAG synthesis: the esterification of a fatty acylCoA to the $s n-3$ position of a diacylglycerol (Conte et al., 2010). Marchitelli et al. (2013) observed that polymorphisms in DGAT1, stearoyl CoA desaturase 1 $(S C D 1)$, and sterol regulatory element binding protein (SREBP-1) genes were associated with variation of milk FA composition among breeds of dairy cattle and within breeds related to stage of lactation. Potential differential effects of C16:0 versus C18:0 in cattle of different genotypes should be investigated.

During the early postpartum period, when cows are in negative energy balance, feeding a lipogenic diet may contribute to significant negative health effects, notably fatty liver syndrome. Such an effect was found by van Knegsel et al. (2007) when a lipogenic diet (including $2 \%$ C16:0 in diet DM) was fed pre- and postparturition compared with a glucogenic diet. Multiparous cows fed the lipogenic diet had similar plasma NEFA, plasma BHBA, plasma cholesterol, and liver TAG in the prepartum period as cows fed the glucogenic diet. Following parturition, cows fed the lipogenic diet had higher plasma NEFA, plasma BHBA, plasma cholesterol, and liver TAG than cows fed the glucogenic diet. Higher concentrations of fat metabolites and liver TAG in cows fed the lipogenic diet were characteristic of cows with fatty liver (>100 mg/g of wet liver weight) and ketosis, 
which were observed in the lipogenic-fed multiparous cows, but not in cows fed the glucogenic diet. The FA composition of plasma NEFA reflects the FA composition of adipose tissue, with C16:0, C18:0, and C18:1 being the predominant FA in plasma NEFA (Douglas et al., 2007; Contreras et al., 2012). Contreras et al. (2012) reported several changes in the inflammatory responses of bovine aortic endothelial tissue, including increased proinflammatory cytokines and enhanced generation of reactive oxygen species when cultures of tissue were treated with amounts and concentrations of plasma NEFA reflecting those found during the transition period. Feeding SFA (C16:0 and 18:0) from $25 \mathrm{~d}$ prepartum until $10 \mathrm{~d}$ postpartum, Akbar et al. (2013) found changes in the profile of metabolic genes associated with the upregulation of $\beta$-oxidation and increased lipid droplet formation. No increase in liver TAG was found, suggesting feeding SFA promoted greater uptake of FA and intracellular handling in hepatic tissue without excessive storage of lipid. Additional research is needed to determine the effects of saturated LCFA on inflammation and transition cow diseases and to delineate differences between C16:0 and C18:0, as C16:0 appears to have a greater propensity to increase in liver tissue postpartum than C18:0.

As indicated previously, C18:0 may be better oxidized by the liver or used as an energy source during the late prepartum and early postpartum periods than C16:0. Karcagi et al. (2010) reported that feeding a diet containing hydrogenated palm oil triacylglycerol (HTG; 69\% C18:0 and 23\% C16:0) provided a better energy supply for high-yielding dairy cows in negative energy balance than calcium salts of palm oil fatty acids (CaS; 33\% C16:0 and 4\% C18:0). Diets were fed for $25 \mathrm{~d}$ prepartum. At $5 \mathrm{~d}$ postpartum, significantly less TAG had accumulated in the liver of cows fed HTG than either the control or CaS. At 5 d postpartum, liver TAG were 6.2-, 4.9-, and 1.9-fold increased in the control, CaS-, and HTG-treated cows, respectively, relative to the value measured at $25 \mathrm{~d}$ prepartum. By $25 \mathrm{~d}$ postpartum, liver TAG were approximately onehalf the concentration measured at $5 \mathrm{~d}$ postpartum and no difference was observed between HTG- and CaS-fed cows. However, cows fed HTG consumed an average of $2.1 \mathrm{~kg} / \mathrm{d}$ more diet DM and produced $7.6 \mathrm{~kg} / \mathrm{d}$ more $4 \%$ FCM during the first $100 \mathrm{~d}$ postpartum than cows fed CaS.

During periods of positive energy balance, supplementation of fat in the diet can lead to increased milk yield, milk fat yield, or BW gain. In ruminants, particularly dairy cows, data on the effects of individual FA on lipogenesis in adipose tissue, liver, and muscle tissue is very limited other than for the primary precursor acetate (Doreau and Chilliard, 1997). The primary site of lipogenesis in cattle is adipose tissue, where FA are synthesized de novo from simple precursors or are derived from dietary lipids (Annison, 1993; Bergen and Mersmann, 2005). In feedlot diets, when $3 \%$ palm oil was added to a control diet $(6.5 \mathrm{~g}$ of $\mathrm{C} 16: 0 / \mathrm{kg}$ of diet) to achieve $20.5 \mathrm{~g}$ of $\mathrm{C} 16: 0 / \mathrm{kg}$ of diet as fed, no change in $\mathrm{C} 16: 0$ or $\mathrm{C} 18: 1$ concentration in adipose tissue was noted. However, C18:0 increased in adipose tissue likely because more C16:0 was elongated to C18:0 and because stearoyl-CoA desaturase activity, which converts C18:0 to C18:1, was inhibited by C16:0 (Choi et al. 2013). This implies feeding supplemental C16:0 can increase body tissue reserves of cows when fed during positive energy balance, but the energy stored will be in the form of $\mathrm{C} 18: 0$ rather than $\mathrm{C} 16: 0$. More research with lactating dairy cows is required to establish this hypothesis. Most of the C18:0 in adipose tissue likely comes from elongation of $\mathrm{C} 16: 0$ and not from direct uptake and esterification of C18:0 into TAG. The preferred substrate for synthesis of TAG is C16:0, whereas C18:0 itself is a poor substrate for TAG synthesis in adipocytes (Sampath and Ntambi, 2005).

\section{MILK AND MILK COMPONENTS}

\section{Lactation Studies}

Numerous studies in the literature have evaluated fat supplementation to lactating dairy cows; however, most of these studies were with supplements containing mixtures of FA. Very few studies have looked at feeding only a single purified form of a FA. The classic studies of Steele and Moore (1968a,b), Noble et al. (1969), and Steele (1969) were some of the first to look at effects of feeding a purified source of C16:0 on milk yield and milk components (Table 4). In their first study, Steele and Moore (1968a) fed $578 \mathrm{~g} / \mathrm{d}$ of highly purified C16:0, which increased milk fat percentage by $0.86 \%$ units and increased the amount of C16:0 in milk fat almost 2-fold, but had no effect on milk yield of $12.2 \mathrm{~kg} / \mathrm{d}$ for control and $11.8 \mathrm{~kg} / \mathrm{d}$ for $\mathrm{C} 16: 0$-supplemented cows. In a later study (Steele 1969), when $446 \mathrm{~g} / \mathrm{d}$ of C16:0 was fed as a replacement for starch in diets of lactating cows, milk yield increased by $1 \mathrm{~kg} / \mathrm{d}$ for cows fed 16:0 compared with control cows. In all 3 studies, feeding C16:0 increased milk fat percentage and yield of C16:0 in milk fat, but concentration and yield of $\mathrm{C} 4$ to $\mathrm{C} 14 \mathrm{FA}$, along with C18:0 and C18:1 in milk fat, decreased. Overall, these studies (Steele and Moore, 1968a; Noble et al., 1969; Steele, 1969) reported a gross transfer of dietary C16:0 into milk fat of $19.9 \%$.

Within the last few years, renewed interest in feeding a concentrated form of $\mathrm{C} 16: 0$ (ca. $85 \%$ of DM) to lactating dairy cows has been observed. Production 
Table 4. Effects of feeding and abomasal infusion of C16:0 and C18:0 on milk FA

\begin{tabular}{|c|c|c|c|c|c|c|c|c|c|}
\hline Item & \multicolumn{3}{|c|}{ Steele and Moore $(1968 \mathrm{a})^{1}$} & \multicolumn{3}{|c|}{ Noble et al. $(1969)^{1}$} & \multicolumn{3}{|c|}{ Enjalbert et al. $(2000)^{2}$} \\
\hline Infused, g/d & & & & & & & & 490 & 460 \\
\hline Milk, kg/d & 12.2 & 11.8 & 12.7 & $\mathrm{NA}^{3}$ & NA & NA & 23.2 & 25.1 & 24.5 \\
\hline Milk fat, $\%$ & 3.31 & $4.17^{*}$ & 3.61 & NA & NA & NA & $3.57^{\mathrm{a}}$ & $4.55^{\mathrm{b}}$ & $4.09^{\mathrm{b}}$ \\
\hline $\mathrm{C} 4: 0-\mathrm{C} 14: 0$ & 21.5 & 13.3 & 18.0 & 27.5 & 17.8 & 20.6 & 24.1 & 20.9 & 24.0 \\
\hline C16:0 & 38.7 & $60.7^{*}$ & $27.7^{*}$ & 36.4 & $49.8^{*}$ & $23.9^{*}$ & $35.5^{\mathrm{a}}$ & $46.2^{\mathrm{b}}$ & $32.4^{\mathrm{a}}$ \\
\hline C16:1, cis-9 & 1.3 & $3.5^{*}$ & 1.2 & 3.1 & $5.2^{*}$ & $2.1^{*}$ & NA & NA & NA \\
\hline C18:0 & 10.1 & $4.3^{*}$ & $18.7^{*}$ & 4.2 & $3.3^{*}$ & $12.5^{*}$ & $8.3^{\mathrm{b}}$ & $7.5^{\mathrm{a}}$ & $12.6^{\mathrm{b}}$ \\
\hline C18:1, cis-9 & 21.3 & $14.2^{*}$ & $30.1^{*}$ & 16.2 & $14.9^{*}$ & $28.7^{*}$ & 18.0 & 15.2 & 19.8 \\
\hline C18:2+18:3 & 2.9 & $1.7^{*}$ & $1.4^{*}$ & 2.0 & $1.3^{*}$ & $1.6^{*}$ & 2.6 & 2.1 & 2.5 \\
\hline
\end{tabular}

\footnotetext{
${ }^{\mathrm{a}, \mathrm{b}}$ Means within a study and response category are different $(P<0.05)$.

${ }^{1}$ Fatty acid-feeding study.

${ }^{2}$ Fatty acids infused into the abomasum.

${ }^{3} \mathrm{NA}=$ not available or determined.

*Means within a study and response category are different from control means, $P<0.05$.
}

results from recent lactation studies (Table 5) are consistent with earlier results from Steele and Moore (1968a), Noble et al. (1969), and Steele (1969), in that feeding C16:0 to lactating dairy cows has more of an effect on milk fat percentage and yield than on milk production. Studies reported in Table 5 all fed between 348 and $545 \mathrm{~g}$ of C16:0 per cow daily. The significant increase in DMI reported by Mosley et al. (2007) at $412 \mathrm{~g} / \mathrm{d}$ did not occur with feeding amounts of 808 or 1,140 g/d of C16:0. Similarly, milk yield and milk fat percentage of cows fed the higher amounts of C16:0 were not significantly different from those fed $412 \mathrm{~g} / \mathrm{d}$. The reason for the increase in DMI when $412 \mathrm{~g} / \mathrm{d}$ was fed is unknown, as no other C16:0 feeding studies have reported an increase in DMI and most all other fat supplement studies report no change or a decrease in DMI. The optimum response in milk fat and 3.5\% FCM to inclusion of C16:0 in the diet was found to be at $1.5 \% \mathrm{C} 16: 0$ in a dose-response study by Rico et al. (2013). Feeding $0.75,1.5$, or $2.25 \%$ of the diet DM as C16:0 increased milk fat percentage by $0.10,0.23$, and $0.25 \%$ units and $3.5 \% \mathrm{FCM}$ by $0.8,2.6$, and $0.5 \mathrm{~kg} / \mathrm{d}$, respectively, over the control diet $(3.78 \%$ milk fat and $45.3 \mathrm{~kg} / \mathrm{d}$ of $3.5 \% \mathrm{FCM}$ ).

All of the studies reported in Table 5 are of short duration, with Warntjes et al. (2008) being the longest at $35 \mathrm{~d}$. This is the only study to report a negative response in milk fat percentage to feeding C16:0. However, consistent with other studies (Steele and Moore, 1968a; Noble et al., 1969; Mosley et al., 2007; Lock et al., 2013), Warntjes et al. (2008) reported that C16:0 concentration in milk fat increased and C18:0 and short-chain FA in milk fat decreased with C16:0 feed- ing. Supplementing cows with $\mathrm{C} 16: 0$ had no effect on milk protein percentage (Table 5 ). Only 2 studies have reported changes in BCS to feeding $\mathrm{C} 16: 0$, with both changes being decreases, but one study used a 21-d feeding period (Piantoni et al., 2013) and the other occurred during summer heat stress (Warntjes et al., 2008).

Very few studies have looked at feeding a pure $(>85 \%)$ C18:0 fat supplement to dairy cattle. The classic study of Steele and Moore (1968a) fed $0.6 \mathrm{~kg} / \mathrm{d}$ of $94 \%$ C18:0 to midlactation dairy cows. They found no change in DMI or milk yield, but milk fat increased 9\% (3.61 vs. $3.31 \%$ ) compared with the no-fat control. Milk fat composition changes included a $200 \%$ increase in C18:0, a $150 \%$ increase in C18:1, and a decrease of about $20 \%$ in C16:0. In later studies (Steele, 1969; Noble et al. 1969), inclusion of 5 and 10\% C18:0 in lactation diets increased milk production 9 and 4\%, respectively. Yields of C18:0 and C18:1 in milk fat increased with supplementation, but concentration of short-chain FA (C10 to C16) in milk decreased. No effect on milk fat percentage with C18:0 supplementation was noted.

Lactation studies comparing supplementation of $\mathrm{C} 16: 0$ and $\mathrm{C} 18: 0$ in diets are few. In the study of Steele and Moore (1968a), feeding $0.6 \mathrm{~kg} / \mathrm{d}$ of C18:0 resulted in a numeric increase in milk yield (12.7 vs. $11.8 \mathrm{~kg} / \mathrm{d}$ ) and a lower milk fat percentage (3.61 vs. $4.17 \%$ ) than feeding the same amount of C16:0. Feeding C18:0 increased yield and concentration of C18:0 and C18:1 in milk fat compared with feeding C16:0; conversely, feeding C16:0 increased yield and concentration of C16:0 in milk fat more than feeding C18:0. Rico et al. (2014) compared feeding highly purified C16:0 
Table 5. Effect of feeding palmitic acid supplements to lactating cows on DMI, milk production, and milk composition

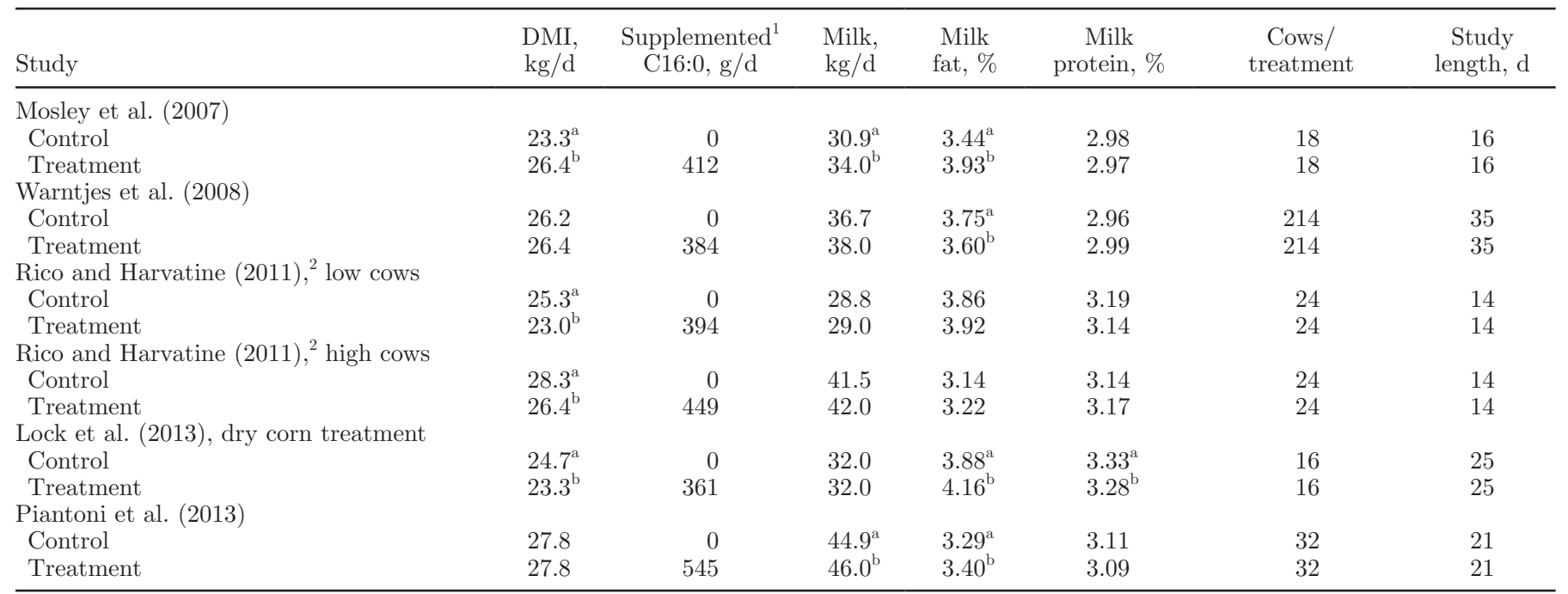

${ }^{\mathrm{a}, \mathrm{b}}$ Means within a study and within a response category with different superscripts are different $(P<0.05)$.

${ }^{1}$ Actual intake of supplemented C16:0. All supplemented sources of C16:0 were $>85 \%$ C16:0.

${ }^{2}$ Data from reference and personal communication from authors.

and $\mathrm{C} 18: 0(>97 \%)$ to early lactation cows at a rate of 642 and $646 \mathrm{~g} / \mathrm{d}$, respectively and found that feeding C16:0 increased $3.5 \%$ FCM $(47.5 \mathrm{~kg} / \mathrm{d}$ vs. $45.6 \mathrm{~kg} / \mathrm{d})$, milk fat concentration $(3.66 \%$ vs. $3.55 \%)$, and milk fat yield $(1.68 \mathrm{~kg} / \mathrm{d}$ vs. $1.59 \mathrm{~kg} / \mathrm{d})$ compared with C18:0. Milk FA proportions of C6:0 to C14:0 were significantly lower for the C16:0 treatment compared with the C18:0 treatment. Yields of de novo-synthesized milk FA (C8:0 to C14:0) were also significantly lower when C16:0 was fed compared with C18:0; however, C16:0 concentration and yield in milk was significantly increased by feeding C16:0. The reduction in proportions and yield of the short- and medium-chain FA is in agreement with Noble et al. (1969) and Steele and Moore (1968a), and indicates supplemental feeding of C16:0 in lactating dairy cow diets depresses de novo synthesis more than stearic acid. Neither FA affected DMI. In a comparison study of C18:0 to C14:0 and C12:0 in lactating cow diets at $40 \mathrm{~g} / \mathrm{kg}$ of diet DM, Dohme et al. (2004) did not find any differences in DMI $(17.9 \mathrm{~kg} / \mathrm{d})$, milk yield $(28.0 \mathrm{~kg} / \mathrm{d})$, or total milk fat FA concentration (4.06\%) between C18:0 and C14:0. Both C18:0 and C14:0 supplementation improved lactation performance over C12:0, which reduced DMI. Supplementation of the diet with C14:0 increased C14:0 and C16:0 in milk fat compared with supplementation of C18:0; however, milk fat content of C18:0 along with total C18 FA were increased with C18:0 supplementation.

A more direct approach than feeding studies to evaluate the transfer of $\mathrm{C} 16: 0$ and $\mathrm{C} 18: 0$ from diet into milk fat is through duodenal infusion. Enjalbert et al. $(1998,2000)$ infused $500 \mathrm{~g} / \mathrm{d}$ of a carrier, C16:0, C18:0, or $\mathrm{C} 18: 1$ into the duodenum of lactating dairy cows. Consistent with feeding studies, midlactation cows fed a high-forage diet (65\% forage, $35 \%$ concentrate) infused with C16:0 had significantly more total FA in milk, a significantly higher concentration of C16:0, and lower concentration of $\mathrm{C} 18: 0$ in milk than noninfused or C18:0-infused cows (Table 4). The total number of FA synthesized in the mammary gland did not decrease with infusion, but mean carbon chain length of FA decreased with infusion, suggesting more C4:0 was secreted into milk to maintain fluidity of milk fat at body temperature. Apparent transfer of the individual FA infused was $46.7 \%$ for C16:0, $49.7 \%$ for $\mathrm{C} 18: 1$, and 12\% for C18:0 (Table 6). Apparent transfer values have limited biological significance because C16:0 is also synthesized in the mammary gland and the quantity synthesized is affected by blood supply of C16:0 to the mammary gland. Similarly, a major portion of cis C18:1 in milk fat comes from desaturation of C18:0, so transfer values of C18:0 alone considerably underestimate the true transfer of C18:0. Combining C18:0 and cis $\mathrm{C} 18: 1$ output in milk results in a calculated transfer efficiency of about 50\% for C18:0 (Enjalbert et al., 2000).

\section{Effect of Energy Balance on C16:0 and C18:0 in Milk Fat}

In periods of negative energy balance, Stoop et al. (2009) reported both C16:0 and C18:0 to be increased in milk fat as cows mobilize adipose tissue for energy. As severity of negative energy balance increased, C16:0 
Table 6. Milk and milk FA response to duodenal infusion of C16:0, C18:0, or C18:1 ${ }^{1}$

\begin{tabular}{|c|c|c|c|c|}
\hline \multirow[b]{2}{*}{ Item } & \multicolumn{4}{|c|}{ Fatty acid infused, $500 \mathrm{~g} / \mathrm{d}$} \\
\hline & Control & C16:0 & C18:0 & C18:1 \\
\hline Milk, $\mathrm{kg} / \mathrm{d}$ & 23.2 & 25.1 & 24.5 & 21.3 \\
\hline Total milk FA, \% & $3.57^{\mathrm{a}}$ & $4.55^{\mathrm{b}}$ & $4.09^{\mathrm{ab}}$ & $4.48^{\mathrm{ab}}$ \\
\hline \multicolumn{5}{|l|}{ Milk FA, \% (wt/wt) } \\
\hline $\mathrm{C} 16: 0$ & $35.54^{\mathrm{a}}$ & $46.21^{\mathrm{b}}$ & $32.41^{\mathrm{a}}$ & $23.29^{\mathrm{b}}$ \\
\hline C18:0 & $8.33^{\mathrm{a}}$ & $7.48^{\mathrm{a}}$ & $12.56^{\mathrm{b}}$ & $6.84^{\mathrm{a}}$ \\
\hline cis $\mathrm{C} 18: 1$ & $17.99^{\mathrm{a}}$ & $15.21^{\mathrm{a}}$ & $19.76^{\mathrm{a}}$ & $37.14^{\mathrm{b}}$ \\
\hline Apparent transfer of infused to milk, $\%$ & & $46.7^{\mathrm{ab}}$ & $12.0^{\mathrm{a}}$ & $49.7^{\mathrm{b}}$ \\
\hline Mean chain length of de novo-synthesized $\mathrm{FA}^{2}$ & $12.0^{\mathrm{a}}$ & $10.7^{\mathrm{b}}$ & $11.1^{\mathrm{ab}}$ & $10.1^{b}$ \\
\hline
\end{tabular}

increased in milk fat more than C18:0, leading to a less favorable milk fat composition. Similarly, Dann et al. (2005) found C16:0 increased and C18:0 decreased in milk fat of early lactation cows fed a restricted energy diet ( $80 \%$ of requirement) during the dry period. Changes in C16:0 and C18:0 in milk fat during negative energy balance are likely more affected by mobilization of adipose tissue in early lactation than intake of dietary C16:0 and C18:0. De novo synthesis of C16:0 decreases in early lactation as plasma LCFA inhibit de novo synthesis of short-chain FA (Bauman and Davis, 1974). In general, stage of lactation only has a small effect on the C16:0 and C18:0 content of milk fat, with C16:0 increasing and C18:0 decreasing before plateauing in midlactation (Dann et al., 2005; Kay et al., 2005). Oleic acid is the predominant FA in adipose tissue and the primary FA released into plasma during negative energy balance from lipolysis of adipose tissue (Rukkwamsuk et al., 2000). Uptake of oleic acid (cis-9 C18:1) by the mammary gland was highest at parturition and during periods of negative energy balance (Dann et al., 2005, Kay et al., 2005) and then decreases slightly as day of lactation increased before plateauing in midlactation.

The infusion study of Enjalbert et al. (1998) also provided insight into utilization of $\mathrm{C} 16: 0, \mathrm{C} 18: 0$, and C18:1 in plasma NEFA and TAG. Infusion of C16:0 significantly raised both $\mathrm{C} 16: 0$ and $\mathrm{C} 18: 0$ in plasma NEFA and TAG. Infusion of C18:0 increased C18:0 and C16:0 in plasma NEFA and TAG, but the increases were less than when C16:0 was infused. Significance of arterial plasma NEFA and TAG differences may be due to rapid incorporation of C18:0 into tissues (BW, milk, or milk fat). This may support a tissue preference for C18:0 as a metabolic energy source to other FA. In contrast, the mammary gland appears to prefer C16:0 for incorporation into milk fat over other FA, at least in the short term. Results from the infusion study of Enjalbert et al. (1998), along with data relating to hepatic metabolism of C16:0 and C18:0 from other studies, support a theory that an LCFA supplement rich in C18:0 in early lactation may be advantageous when compared with one rich in C16:0. During periods of positive energy balance (after peak milk), a higher amount of C16:0 than C18:0 in fat supplementation may be preferred for a positive effect on milk fat percentage.

\section{PALMITIC AND STEARIC ACID REGULATION IN MILK FAT}

\section{Chain Length Effects}

Early work summarized by Palmquist and Jenkins (1980) concluded that $50 \%$ of FA in milk are synthesized de novo in the mammary gland, 40 to $45 \%$ are from the diet, and less than $10 \%$ are from adipose tissue. Fatty acids from $\mathrm{C} 4$ to $\mathrm{C} 14$ are synthesized de novo in the mammary gland from blood acetate and BHBA, whereas C16:0 arises from both de novo synthesis and plasma TAG. Long-chain FA, predominantly C18 FA, in milk fat are derived from plasma TAG (Palmquist et al., 1969; Moore and Christie, 1979), with about $88 \%$ of TAG originating from intestinal lipoproteins and $12 \%$ from endogenous origin (Palmquist and Mattos, 1978). Primary circulating precursors of milk FA include acetate (de novo synthesis), plasma TAG, plasma FFA, sterols, sterol esters, and plasma phospholipids. Annison et al. (1967) observed little mammary uptake of plasma FFA, sterols, sterol esters, or phospholipids in undisturbed lactating goats. They also observed that FA of chain length $\mathrm{C} 4$ to $\mathrm{C} 14$ were mainly from plasma acetate and C16:0 was from both plasma acetate and plasma TAG, whereas C18:0 and C18:1 in milk fat were almost solely from plasma TAG.

Milk fat composition and concentration are variable and affected by diet and fat supplementation (Palmquist, 2006). Changes in milk FA composition do occur with feeding of fats differing in FA composition 
and the amount of fat included in the diet (Moate et al., 2007). Of specific interest is the change in milk fat concentration and composition invoked by feeding a fat supplement high (>80\%) in C16:0 or C18:0. As shown previously, feeding a fat supplement high in $\mathrm{C} 16: 0$ or C18:0 can increase these FA in milk fat. However, the amounts of these FA found in milk fat are considerably less than the amount fed or infused, and at high concentrations in the diet they can alter the concentration and yield of other FA in milk fat. Beyond the previously discussed factors affecting transfer of C16:0 and C18:0 into milk fat, the need to maintain fluidity of milk fat also may be a regulator of the amount of these 2 FA found in milk fat, particularly C16:0, as a terminal SFA, whereas C18:0 may be desaturated to C18:1 in the mammary gland.

Several studies have found a significant increase in C16:0 in milk fat when a highly concentrated source of C16:0 was either fed (Steele and Moore, 1968a; Noble et al., 1969; Lock et al. 2013) or infused (Enjalbert et al., 1998, 2000). Corresponding to the increase in C16:0 were decreasing proportions of $\mathrm{C} 4: 0$ to $\mathrm{C} 14: 0, \mathrm{C} 18: 0$, C18:1, C18:2, and C18:3 in milk fat. When similar C18:0 treatments were applied, C16:0 in milk fat was decreased, but short-chain FA, C18:0, and C18:1 were not affected (Table 4). Feeding a highly concentrated C16:0 fat supplement influences the proportion of C18:0 in milk fat and vice versa. Reductions in short- and medium-chain FA in milk, when milk fat depression is not a factor, are primarily due to increased concentrations of LCFA from plasma TAG available to the mammary gland. These LCFA have been shown to decrease activity of acetyl CoA carboxylase, which is the primary regulatory step for FA synthesis (Ganguly 1960). Other studies (Steele and Moore, 1968b; Drackley et al., 1992; Relling and Reynolds, 2007) revealed that when mixtures of C16:0 and C18:0 were fed or infused in lactating cows, proportions of $\mathrm{C} 16: 0$ and the sum of $\mathrm{C} 18: 0$, C18:1, C18:2, and C18:3 were not depressed but were increased. These results indicate that when the lactating cow is not experiencing milk fat depression and the concentrations of acetate and BHBA are adequate as precursors for de novo synthesis of milk fat, then synthesis of milk fat will rely on supply and balance of C16:0 and C18:0 for normal milk FA composition.

\section{Milk TAG Composition}

Jensen (2002) showed that the structure of milk TAG is responsible for the melting points, crystalline behavior, and rheological properties of milk fat globules. Based on the melting point of the major FA found in milk (Table 7), the lactating cow selectively incorporates FA into milk fat globules that maintain the fluidity of milk (Timmen and Patton, 1988). In the $s n$-glycerol 3-phosphate pathway, the main pathway of TAG synthesis in the lactating cow, the glycerol 3-phosphate is acylated sequentially on positions $s n-1$ and $s n$-2 to form phosphatidic acid. The enzyme phosphatide phosphatase hydrolyzes the phosphate at the $s n$-3 position, resulting in the formation of diacylglycerol. The diacylglycerol is acylated by specific acyltransferases to form TAG (Moore and Christie 1979). The $s n$-3 position is acylated last in the biosynthesis of TAG. Jensen (2002) concluded that for liquidity of the milk fat globule, most of the FA must be esterified to TAG in combinations that have a melting point lower than $39^{\circ} \mathrm{C}$, the body temperature of the cow. Timmen and Patton (1988) suggested that stearoyl CoA desaturase maintains the fluidity of the cellular endoplasmic reticulum membrane and plays a key role in regulating milk fat globule fluidity. Hansen and Knudsen (1987) reported that when C16:0 was added to an incubation of bovine mammary epithelial cells, a strong stimulatory response in de novo synthesis and the incorporation of butyrate into FA was observed. They concluded that FA preferentially incorporated into the $s n-1$ or $s n$-2 position on the TAG would strongly stimulate de novo synthesis. This apparently occurs due to the necessity to fill the $s n-3$ position with a lower melting point FA, such as C6:0 and C8:0, when C16:0 is in the medium. Likewise, when C18:1 was added to the medium, it had a marked inhibitory effect of de novo synthesis. They further concluded that FA preferentially incorporated into the $s n$-3 position or equally well in all positions will inhibit de novo synthesis by competing with short- and medium-chain FA for positions $s n$-2 and $s n$-3. Their conclusion was that $\mathrm{C} 16: 0$ and $\mathrm{C} 12: 0$ are the most beneficial FA to include in the diet to increase lipid biosynthesis in the mammary gland. This may be true for de novo synthesis, but milk fat contains about $50 \%$ LCFA, of which $80 \%$ of those LCFA are C18 FA. These C18 FA are derived from blood TAG, which are 95\% dietary origin (Palmquist and Conrad, 1971). Including C16:0 into the medium would be expected to stimulate de novo synthesis to create precursors for milk FA incorporation into TAG with low melting points. This would support the positioning of FA on the TAG to maintain milk fluidity and the absolute limits of high-melting point LCFA, such as C16:0 and C18:0 in milk fat.

Positioning of FA on the milk fat TAG is the process by which the lactating cow maintains the fluidity of milk fat. Higher melting point FA are loaded on the $s n-1$ and $s n-2$ positions, and the $s n-3$ position is reserved primarily for the FA with a lower melting points, such as C4:0, C6:0, C8:0, and C18:1. That the lactating cow must maintain the fluidity of milk places practical 
Table 7. Milk fat triglyceride composition and positioning of various FA at the $s n-1, s n$-2, and $s n$-3 positions and their corresponding melting points $^{1}$

\begin{tabular}{lrrrrrrrrr}
\hline & \multicolumn{9}{c}{ FA } \\
\cline { 2 - 8 } Item & C4:0 & C6:0 & C8:0 & C10:0 & C12:0 & C14:0 & C16:0 & C18:0 & C18:1 \\
\hline Triglyceride position & & & & & & & & \\
sn-1 & 1.6 & 3.1 & 10.3 & 15.2 & 23.7 & 27.3 & 44.1 & 54.0 & 37.3 \\
sn-2 & 0.3 & 3.9 & 55.2 & 56.6 & 62.9 & 65.6 & 45.4 & 16.2 & 21.2 \\
sn-3 & 48.1 & 93.0 & 34.5 & 28.2 & 13.4 & 7.1 & 10.5 & 29.8 & 41.5 \\
Melting point, ${ }^{\circ} \mathrm{C}$ & -7.9 & -3.4 & 16.7 & 31.6 & 43.2 & 54.4 & 62.9 & 69.6 & -13.4 \\
\hline
\end{tabular}

${ }^{1}$ Adapted from Jensen (2002). Percentage of FA in the $s n$ position.

limits on incorporation of high-melting point FA, such as C16:0 and C18:0, in milk fat. An example of unregulated amounts of stearic acid being incorporated into the milk fat TAG and reducing fluidity and hardening of milk fat was observed in a study by Emanuelson et al. (1991), which they could not repeat. The C18:0 content of milk fat was $28.8 \%$ (wt/wt), resulting in floating milk fat globules immediately upon milking. Levels of C16:0 and C18:1 in the milk fat were considered normal, but short- and medium-chain FA were low. Thus, the need to maintain fluidity of milk fat precludes the transfer of all absorbed C16:0 or C18:0 in concentrated fat supplements into milk fat. Studies feeding a highly purified source of either C16:0 or C18:0 have shown changes in milk fat composition reflecting FA being fed. All but one (Warntjes et al., 2008) of the C16:0 studies (Table 5) had a significant or numeric increase in milk fat percentage compared with the control (no added dietary fat). An unknown is whether homeostatic mechanisms for milk fat percentage and composition will prevail over time to maintain fluidity of milk when a highly purified source of a single SFA is fed. All recent feeding studies with purified FA were of short duration, the longest being $35 \mathrm{~d}$ by Warntjes et al. (2008) who found a decrease in milk fat percentage and almost no change in milk fat composition with feeding C16:0 compared with a control. A possible explanation for these varied results may be related to energy balance or stage of lactation of the experimental lactating cows. Gross et al. (2011) observed C4 to C16 milk FA increased with decreasing negative energy balance and C18:0 and cis-9 C18:1 milk FA decreased as mobilization of adipose tissue declined in early lactation cows. Similar changes in milk FA composition were observed when energy intake was restricted to $49 \%$ of requirements for cows starting at 100 DIM. The negative energy balance caused by the restricted intake resulted in less pronounced changes in milk FA composition and tended to adjust to the initial composition.

Because milk fat is a combination of FA, supplementation of both C16:0 and C18:0 in lactating dairy cow diets may achieve better utilization than when fed alone. Kadegowda et al. (2008) infused into the abomasum of early lactation cows as (1) no infusion (control); (2) $400 \mathrm{~g} / \mathrm{d}$ of butterfat; or (3) $245 \mathrm{~g} / \mathrm{d}$ of an LCFA mixture that provided $50 \%$ of the $\mathrm{C} 16: 0$ and equivalent amounts of $\mathrm{C} 18 \mathrm{FA}$ as found in $400 \mathrm{~g}$ of butterfat. It was anticipated the other $50 \%$ of the needed C16:0 for milk fat would be synthesized de novo. Infusing butterfat that had $26.7 \mathrm{~g}$ of $\mathrm{C} 16 / 100 \mathrm{~g}$ of FA and $11.4 \mathrm{~g}$ of $\mathrm{C} 18: 0 / 100 \mathrm{~g}$ of FA significantly increased milk fat percentage $(14 \%)$, milk fat yield $(21 \%)$, and milk yield $(6.0 \%)$ over the control. Milk FA proportions (shortchain FA, C16:0, C18:0, C18:1, C18:2, and C18:3) were similar for the butterfat-infused cows compared with control cows (Table 8). Infusion of LCFA had no effect on either milk fat percentage or milk fat yield, although milk fat yield was numerically (8.5\%) higher compared with controls. It appears that optimal utilization of C16:0 and C18:0 for lactation performance may be when both FA are supplemented in a combination that ranges from 1:1 to 2:1 of C16:0:C18:0.

\section{CONCLUSIONS}

The research reviewed indicates that both $\mathrm{C} 16: 0$ and C18:0 have specific roles and functions in metabolism, but also complementary roles in dairy cows. Stearic acid is the predominant FA absorbed by lactating dairy cows, with more than 2.5 times the amount entering the duodenum than the next FA, C16:0. Percentage of absorption of C16:0 and C18:0 from the duodenum are essentially equal, with cows having evolved a system utilizing lysolecithin to effectively absorb large quantities of C18:0 from the intestine. Within the cow, C16:0 is found in greater concentrations than C18:0 in adipose tissue, plasma NEFA, and liver TAG. In negative energy balance, C18:0 does not appear to accumulate in liver tissue such as C16:0, leading to the possibility C18:0 may be specifically used by the liver for oxidation or secreted through milk.

Palmitic acid is the primary FA in milk fat and is found at 2.5 to 3 times greater concentration than C18:0. However, the sum of $\mathrm{C} 18: 1$ and C18:0 about 
Choi, S. H., G. O. Gang, J. E. Sawyer, B. J. Johnson, K. H. Kim, C. W. Choi, and S. B. Smith. 2013. Fatty acid biosynthesis and lipogenic enzyme activities in subcutaneous adipose tissue of feedlot steers fed supplementary palm oil or soybean oil. J. Anim. Sci. 91:2091-2098.

Conte, G., M. Mele, S. Chessa, B. Castiglioni, A. Serra, G. Pagnacco, and P. Secchiari. 2010. Diacylglycerol acyltransferase 1, stearoylCoA desaturase 1 , and sterol regulatory element binding protein 1 gene polymorphisms and milk fatty acid composition in Italian Brown cattle. J. Dairy Sci. 93:753-763.

Contreras, G. A., W. Raphael, S. A. Mattmiller, J. Gandy, and L. M. Sordillo. 2012. Nonesterified fatty acids modify inflammatory response and eicosanoid biosynthesis in bovine endothelial cells. J. Dairy Sci. 95:5011-5023.

Contreras, G. A., and L. M. Sordillo. 2011. Lipid mobilization and inflammatory responses during the transition period of dairy cows. Comp. Immunol. Microbiol. Infect. Dis. 34:281-289.

Dann, H. M., D. E. Morin, G. A. Bollero, M. R. Murphy, and J. K. Drackley. 2005. Prepartum intake, postpartum induction of ketosis, and periparturient disorders affect the metabolic status of dairy cows. J. Dairy Sci. 88:3249-3264.

Demeyer, D., and M. Doreau. 1999. Targets and procedures for altering ruminant meat and milk lipids. Proc. Nutr. Soc. 58:593-607.

Dohme, F., A. Machmuller, F. Sutter, and M. Kreuzer. 2004. Digestive and metabolic utilization of lauric, myristic and stearic acid in cows and associated effects on milk fat quality. Arch. Anim. Nutr. 58:99-116.

Doreau, M. 1992. Effects of supplementation with hydrogenated fish fat on digestion in dairy cows. Ann. Zootech. 41:137-143.

Doreau, M., and Y. Chilliard. 1997. Digestion and metabolism of dietary fat in farm animals. Br. J. Nutr. 78(Suppl. 1):S15-S35.

Doreau, M., and A. Ferlay. 1994. Digestion and utilization of fatty acids by ruminants. Anim. Feed Sci. Technol. 45:379-396.

Douglas, G. N., J. Rehage, A. D. Beaulieu, A. O. Bahaa, and J. K. Drackley. 2007. Prepartum nutrition alters fatty acid composition in plasma, adipose tissue, and liver lipids of periparturient dairy cows. J. Dairy Sci. 90:2941-2959.

Drackley, J. K. 1999. Biology of dairy cows during the transition period: The final frontier? J. Dairy Sci. 82:2259-2273.

Drackley, J. K. 2000. Lipid metabolism. Pages 97-119 in Farm Animal Metabolism and Nutrition. J. P. F. D'Mello, ed. CABI Publishing, New York, NY.

Drackley, J. K., T. H. Klusmeyer, A. M. Trusk, and J. H. Clark. 1992. Infusion of long-chain fatty acids varying in saturation and chain length into the abomasum of lactating dairy cows. J. Dairy Sci. 75:1517-1526.

Emanuelson, M., M. Murphy, and J. E. Lindberg. 1991. Effects of heat-treated and untreated fat rapeseed and tallow on rumen metabolism, digestibility, milk composition, and milk yield in lactating cows. Anim. Feed Sci. Technol. 34:291-309.

Enjalbert, F., M. Nicot, C. Bayourthe, and R. Moncoulon. 1998. Duodenal infusions of palmitic, stearic or oleic acids differently affect mammary gland metabolism of fatty acids in lactating dairy cows. J. Nutr. 128:1525-1532.

Enjalbert, F., M. Nicot, C. Bayourthe, and R. Moncoulon. 2000. Effects of duodenal infusions of palmitic, stearic, or oleic acids on milk composition and physical properties of butter. J. Dairy Sci. 83:1428-1433.

Freeman, C. P. 1969. Properties of fatty acids in dispersions of emulsified lipid and bile salt and the significance of these properties in fat absorption in the pig and the sheep. Br. J. Nutr. 23:249-263.

Ganguly, J. 1960. Study on the mechanism of fatty acid synthesis. VII. Biosynthesis of fatty acids from malonyl CoA. Biochim. Biophys. Acta 40:110-118.

Glasser, F., M. Doreau, A. Ferlay, J. Loor, and Y. Chilliard. 2007. Milk fatty acid: Milk synthesis could limit transfer from duodenum in cows. Eur. J. Lipid Sci. Technol. 109:817-827.

Glasser, F., A. Ferlay, M. Doreau, P. Schmidely, D. Sauvant, and Y. Chilliard. 2008a. Long-chain fatty acid metabolism in dairy cows: A meta-analysis of milk fatty acid yield in relation to duodenal flows and de novo synthesis. J. Dairy Sci. 91:2771-2785.
Glasser, F, P. Schmidely, D. Sauvant, and M. Doreau. 2008b. Digestion of fatty acids in ruminants: A meta-analysis of flows and variation factors. 1. C18 fatty acids. Animal 2:691-704.

Gross, J., H. A. van Dorland, R. M. Bruckmaier, and F. Schwarz. 2011. Milk fatty acid profile related to energy balance in dairy cows. J. Dairy Res. 78:479-488.

Grummer, R. R. 1993. Etiology of lipid-related metabolic disorders in periparturient dairy cows. J. Dairy Sci. 76:3882-3896.

Hansen, H. O., and J. Knudsen. 1987. Effect of exogenous long-chain fatty acids on individual fatty acid synthesis by dispersed ruminant mammary gland cells. J. Dairy Sci. 70:1350-1354.

Jenkins, T. C., R. J. Wallace, P. J. Moate, and E. E. Mosley. 2008. Board-invited review: Recent advances in biohydrogenation of unsaturated fatty acids within the rumen microbial ecosystem. J. Anim. Sci. 86:397-412.

Jensen, R. G. 2002. The composition of bovine milk lipids: January 1995 to December 2000. J. Dairy Sci. 85:295-350.

Kadegowda, A. K. G., L. S. Piperova, P. Delmonte, and R. A. Erdman. 2008. Abomasal infusion of butterfat increases milk fat in lactating dairy cows. J. Dairy Sci. 91:2370-2379.

Karcagi, R. G., T. Gaál, P. Ribiczey, G. Huszenicza, and F. Husvéth. 2010. Milk production, peripartal liver triacylglycerol concentration and plasma metabolites of dairy cows fed diets supplemented with calcium soaps or hydrogenated triacylglycerols of palm oil. J. Dairy Res. 77:151-158.

Kay, J. K., W. J. Weber, C. E. Moore, D. E. Bauman, L. B. Hansen, H. Chester-Jones, B. A. Crooker, and L. H. Baumgard. 2005. Effects of week of lactation and genetic selection for milk yield on milk fatty acid composition in Holstein cows. J. Dairy Sci. 88:3886-3893.

Kucuk, O., B. W. Hess, and D. C. Rule. 2004. Soybean oil supplementation of a high concentrate diet does not affect site and extent of organic matter, starch, neutral detergent fiber, or nitrogen digestion, but influences both ruminal metabolism and intestinal flow of fatty acids in limit-fed lambs. J. Anim. Sci. 82:2985-2994.

Lemay, P., and R. Oesper. 1948. Michel Eugene Chevreul (1786-1889). J. Chem. Educ. 25:62-70.

Litherland, N. B., H. M. Dann, and J. K. Drackley. 2011. Prepartum nutrient intake alters palmitate metabolism by liver slices from peripartal dairy cows. J. Dairy Sci. 94:1928-1940.

Lock, A. L., K. J. Harvatine, J. K. Drackley, and D. E. Bauman. 2006. Concepts in fat and fatty acid digestion in ruminants. Pages 85 100 in Proc. Intermountain Nutr. Conf. Utah State Univ., Logan.

Lock, A. L., C. L. Preseault, J. E. Rico, K. E. DeLand, and M. S. Allen. 2013. Feeding a C16:0-enriched fat supplement increased the yield of milk fat and improved conversion of feed to milk. J. Dairy Sci. 96:6650-6659.

Loor, J. J., K. Ueda, A. Ferlay, Y. Chilliard, and M. Doreau. 2004. Biohydrogenation, duodenal flow, and intestinal digestibility of trans fatty acids and conjugated linoleic acids in response to dietary forage:concentrate ratio and linseed oil in dairy cows. J. Dairy Sci. 87:2472-2485.

Marchitelli, C., G. Contarini, G. De Matteis, A. Crisà, L. Pariset, M. C. Scatà, G. Catillo, F. Napolitano, and B. Moioli. 2013. Milk fatty acid variability: Effect of some candidate genes involved in lipid synthesis. J. Dairy Res. 80:165-173.

Mashek, D. G., and R. R. Grummer. 2003a. Short communication: Net uptake of nonesterified long chain fatty acids by the perfused caudate lobe of the caprine liver. J. Dairy Sci. 86:1218-1220.

Mashek, D. G., and R. R. Grummer. 2003b. Effects of long chain fatty acids on lipid and glucose metabolism in monolayer cultures of bovine hepatocytes. J. Dairy Sci. 86:2390-2396.

Moate, P. J., W. Chalupa, R. C. Boston, and I. J. Lean. 2007. Milk fatty acids. I. Variation in the concentration of individual fatty acids in bovine milk. J. Dairy Sci. 90:4730-4739.

Moore, J. H., and W. W. Christie. 1979. Lipid metabolism in the mammary gland of ruminant animals. Prog. Lipid Res. 17:347-395.

Mosley, S. A., E. E. Mosley, B. Hatch, J. I. Szasz, A. Corato, N. Zacharias, D. Howes, and M. A. McGuire. 2007. Effect of varying levels of fatty acids from palm oil on feed intake and milk production in Holstein cows. J. Dairy Sci. 90:987-993. 
Nakamura, M. T., B. E. Yudell, and J. L. Loor. 2014. Regulation of energy metabolism by long-chain fatty acids. Prog. Lipid Res. $53: 124-144$.

Noble, R. C., W. Steele, and J. H. Moore. 1969. The effects of dietary palmitic and stearic acids on milk fat composition in the cow. J. Dairy Res. 36:375-381.

Palmquist, D. L. 2006. Milk fat: Origin of fatty acids and influence of nutritional factors. Pages 43-92 in Advanced Dairy Chemistry. Lipids, 3rd ed. Vol. 2. P. F. Fox and P. L. H. Sweeney, ed. Springer, New York, NY.

Palmquist, D. L., and H. R. Conrad. 1971. Origin of plasma fatty acids in lactating cows fed high grain or high fat diets. J. Dairy Sci. 54:1025-1033.

Palmquist, D. L., C. L. Davis, R. E. Brown, and D. S. Sachan. 1969. Availability and metabolism of various substrates in ruminants. V. Entry rate into the body and incorporation into milk fat of $\mathrm{D}(-)$ hydroxybutyrate. J. Dairy Sci. 52:633-638.

Palmquist, D. L., and T. C. Jenkins. 1980. Fat in lactation rations: Review. J. Dairy Sci. 63:1-14.

Palmquist, D. L., and W. Mattos. 1978. Turnover of lipoproteins and transfer to milk fat of dietary (1-carbon-14) linoleic acid in lactating cows. J. Dairy Sci. 61:561-565.

Piantoni, P., A. L. Lock, and M. S. Allen. 2013. Palmitic acid increased yields of milk and milk fat and nutrient digestibility across production level of lactating cows. J. Dairy Sci. 96:7143-7154.

Relling, A. E., and C. K. Reynolds. 2007. Feeding rumen-inert fats differing in their degree of saturation decreases intake and increases plasma concentrations of gut peptides in lactating dairy cows. J. Dairy Sci. 90:1506-1515.

Rico, D. E., and K. J. Harvatine. 2011. Effect of a high palmitic acid fat supplement on ruminal fermentation and milk yield in highand low-producing dairy cows. J. Dairy Sci. 94(E-Suppl.):133. (Abstr.)

Rico, J. E., M. S. Allen, and A.L. Lock. 2013. Milk yield and milk fat responses to increasing levels of palmitic acid supplementation of dairy cows receiving low and high fat diets. J. Dairy Sci. 96(ESuppl.):651. (Abstr.)

Rico, J. E., M. S. Allen, and A. L. Lock. 2014. Compared with stearic acid, palmitic acid increased the yield of milk fat and improved feed efficiency across production level of cows. J. Dairy Sci. 97:1057-1066.

Rukkwamsuk, T., M. J. H. Geelen, T. A. M. Kruip, and T. Wensing. 2000. Interrelation of fatty acid composition in adipose tissue, serum, and liver of dairy cows during the development of fatty liver postpartum. J. Dairy Sci. 83:52-59.

Sampath, H., and J. M. Ntambi. 2005. The fate and intermediary metabolism of stearic acid. Lipids 40:1187-1191.

Sato, H., and A. Inoue. 2006. Decrease in stearic acid proportions in adipose tissues and liver lipids in fatty liver of dairy cows. Anim. Sci. J. 77:347-351.
Sauvant, D., and P. Bas. 2001. Lipid digestion in ruminants. INRA Prod. Anim. 14:303-310.

Schennink, A., W. M. Stoop, M. H. P. W. Visker, J. M. L. Heck, H. Bovenhuis, J. J. van der Poel, H. J. F. van Valenberg, and J. A. M. van Arendonk. 2007. DGAT1 underlies large genetic variation in milk-fat composition of dairy cows. Anim. Genet. 38:467-473.

Schmidely, P., F. Glasser, M. Doreau, and D. Sauvant. 2008. Digestion of fatty acids in ruminants: A meta-analysis of flows and variation factors. 1. Total fatty acids. Animal 2:677-690.

Smith, S. B., D. K. Lunt, K. Y. Chung, C. B. Choi, R. K. Tume, and M. Zembayashi. 2006. Adiposity, fatty acid composition, and delta-9 desaturase activity during growth in beef cattle. Anim. Sci. J. 77:478-486.

Steele, W. 1969. The effects of dietary palmitic and stearic acids on milk production yield and composition in the cow. J. Dairy Res. 36:369-373.

Steele, W., and J. H. Moore. 1968a. The effects of a series of saturated fatty acids in the diet on milk-fat secretion in the cow. J. Dairy Res. 35:361-370.

Steele, W., and J. H. Moore. 1968b. The effects of mono-unsaturated and saturated fatty acids in the diet on milk-fat secretion in the cow. J. Dairy Res. 35:353-360.

Stoop, W. M., H. Bovenhuis, J. M. L. Heck, and A. M. van Arendonk. 2009. Effect of lactation stage and energy status on milk fat composition of Holstein-Friesian cows. J. Dairy Sci. 92:1469-1478.

Sukhija, P. S., and D. L. Palmquist. 1990. Dissociation of calcium soaps of long-chain fatty acids in rumen fluid. J. Dairy Sci. 73:1784-1787.

Timmen, H., and S. Patton. 1988. Milk fat globules: Fatty acid composition, size and in vivo regulation of fat liquidity. Lipids 23:685689.

van Knegsel, A. T. M., H. van den Brand, J. Dijkstra, W. M. van Straalen, R. Jorritsma, S. Tamminga, and B. Kemp. 2007. Effect of glucogenic vs. lipogenic diets on energy balance, blood metabolites, and reproduction in primiparous and multiparous dairy cows in early lactation. J. Dairy Sci. 90:3397-3409.

Warntjes, J. L., P. H. Robinson, E. Galo, E. J. DePeters, and D. Howes. 2008. Effects of feeding supplemental palmitic acid (C16:0) on performance and milk fatty acid profile of lactating dairy cows under summer heat. Anim. Feed Sci. Technol. 140:241-258.

White, H. M., S. L. Koser, and S. S. Donkin. 2011. Differential regulation of bovine pyruvate carboxylase promoters by fatty acids and peroxisome proliferator-activated receptor- $\alpha$ agonist. J. Dairy Sci. 94:3428-3436.

Wu, Z., O. A. Ohajuruka, and D. L. Palmquist. 1991. Ruminal synthesis, biohydrogenation, and digestibility of fatty acids by dairy cows. J. Dairy Sci. 74:3025-3034 